\title{
Volatile composition, olfactometry profile and sensory evaluation of semi-hard Spanish goat cheeses
}

\author{
Justa María PovedA ${ }^{1,2, *}$, Eva SÁNCHEZ-PALOMO ${ }^{2}$, \\ María Soledad PÉREZ-CoELlO ${ }^{2}$, Lourdes CABEZAS ${ }^{1}$
}
${ }^{1}$ Instituto Regional de Investigación Científica Aplicada (IRICA), Departamento de Química Analítica y Tecnología de Alimentos, Universidad de Castilla La Mancha, Ciudad Real, Spain
${ }^{2}$ Departamento de Química Analítica y Tecnología de Alimentos, Facultad de Ciencias Químicas, Universidad de Castilla La Mancha, Ciudad Real, Spain

Received 13 April 2007 - Accepted 23 October 2007

\begin{abstract}
The volatile compounds of several semi-hard goat's milk cheeses from different regions of Spain were isolated by Steam Distillation Extraction (SDE) and analysed by Gas Chromatography-Mass Spectrometry (GC-MS) and Gas Chromatography-Sniffing. About 50 volatile compounds were identified from GC-MS analysis. Of these, the compounds contributing most to cheese aroma were short-chain fatty acids, especially 3-methylbutanoic acid (sweat, acid, rancid), a large number of ketones (dairy, cooked), some lactones including $\delta$-decalactone (fruity), ethyl esters of hexanoic and dodecanoic acid (fruity), some benzene compounds including phenylacetaldehyde (dry fruit) and also 1-hexanol (green). Principal Component Analysis of the volatile compounds distinguished four cheeses from the rest in terms of their different content in some volatile compounds, i.e., 2-phenylethanol, decanoic acid ethyl ester, 2-pentadecanone, octanoic acid, tetradecanoic acid, 3-hydroxy-2-butanone, 2-heptanone, 2-nonanone and 2-heptanol. A good correlation between some sensory attributes and specific volatile compounds was observed, e.g., medium-chain fatty acids (octanoic, decanoic and tetradecanoic acids) correlated positively $(P<0.05)$ with animal odour.
\end{abstract}

goat cheese / volatile compounds / GC-MS / olfactometry / sensory attributes

摘要 - 西班牙半硬质山羊奶干酪挥发性成分、风味及感官评价。本文采用水蒸气蒸馏提 取法、气-质联用和气相色谱-气味测定法测定了西班牙不同地区的半硬质山羊奶干酪中挥 发性化合物。采用气-质色谱法鉴定出约有 50 种挥发性化合物。实验结果表明这些挥发性 化合物中对干酪香气起主要作用的是一些短链脂肪酸, 特别是 3-甲基丁酸 (甜味、酸味、腐 嗅味)、多种酮类化合物 (奶味、蒸煮味)、内酯类如 $\delta$-癸内酯 (水果味)、己酸乙酯和十二碳 酸 (水果味) 、苯系物如苯乙醛 (干果味) 、以及正-己醇 (青草味)。本文还采用主成分分析 法对这些挥发性化合物进行了聚类分析, 根据特殊挥发性化合物的含量不同将四种山羊干 奶酪与其它的山羊奶干酪加以区别。这些化合物分别是 2-苯基乙醇、癸酸乙酯、2-十五烷 酮、辛酸、肉豆冦酸、3-羟基-2-丁酮、2-庚酮、2-壬酮以及 2-庚醇。实验结果表明:山羊奶 干酪的感官性质与一些特殊的挥发性化合物含量之间具有较好的相关性, 中链脂肪酸含量 (辛酸、癸酸、肉豆冦酸) 与动物固有的气味呈正相关 $(P<0.05)$ 。

山羊奶干酪 / 挥发性化合物 / 气-质联用 / 气味测定法 / 感官特性

* Corresponding author (通讯作者): justamaria.poveda@uclm.es 


\begin{abstract}
Résumé - Composés volatils, profil olfactométrique et évaluation sensorielle de fromages de chèvre espagnols à pâte semi-dure. Les composés volatils de plusieurs fromages de chèvre à pâte semi-dure de différentes régions d'Espagne ont été extraits par distillation à la vapeur et analysés par chromatographie en phase gazeuse couplée à la spectrométrie de masse (CG-SM) et par chromatographie en phase gazeuse-sniffing. Environ 50 composés volatils ont été identifiés par CG/SM. Parmi ceux-ci, les composés trouvés comme contribuant le plus à l'arôme du fromage ont été les acides gras à courte chaîne, en particulier l'acide 3-méthylbutanoïque (doux, acide, rance), un grand nombre de cétones (lait, cuit), quelques lactones incluant la $\delta$-decalactone (fruité), les esters d'éthyle d'acide hexanoïque et dodecanoïque (fruité), quelques composés benzèniques incluant le phénylacétaldéhyde (fruit sec) et aussi l'1-hexanol (vert). L'analyse en composantes principales des composés volatils a distingué 4 fromages, ayant par rapport aux autres des teneurs différentes en quelques composés volatils, à savoir le 2-phényléthanol, l'ester d'éthyle d'acide decanoïque, la 2-pentadecanone, l'acide octanoïque, l'acide tetradecanoïque, la 3-hydroxy-2-butanone, la 2-heptanone, la 2-nonanone et le 2-heptanol. Une bonne corrélation était observée entre certains attributs sensoriels et certains composés volatils spécifiques, par exemple les acides gras à chaîne moyenne (octanoïque, decanoïque et tetradecanoïque) étaient positivement corrélés $(P<0,05)$ avec l'odeur animale.
\end{abstract}

\title{
fromage de chèvre / composés volatils / CG-SM / olfactométrie / attributs sensoriels
}

\section{INTRODUCTION}

Numerous varieties of goat's milk cheese are produced worldwide, depending on the geographical localisation, milk composition and the technology used in the cheesemaking process. Until recently, in Spain, goat's milk has been less appreciated than ewe's milk for cheese production, being used for the manufacture of mixed milk (cow's, ewe's and goat's) cheese. However, goat cheese consumption is undergoing a recovery process due to the support of programmes for the development of the rural environment, promoted by regional and European governments. Almost the whole of Spain's goat's milk production of around $363800 \mathrm{t}$ [25] is used for cheesemaking. Annual goat cheese production in Spain is roughly $14100 \mathrm{t}$ [25]. Around thirty varieties of goat's milk cheeses are manufactured in Spain; however, only four of them are protected by a Denomination of Origin.

Cheese aroma is a very complex perception, as it is the outcome of the action of many compounds that may also be found in other foods of different kinds [34] and it is considered as a quality element of great relevance for cheesemakers. Most cheese varieties contain similar volatile compounds but in different proportions. The concentrations and proportions of volatile and non-volatile flavour compounds are probably responsible for the specific flavour of each variety [12].

The specific aroma of goat cheese has been well identified by different authors [9, 10, 16, 21, 22, 29, 31]. 4-Methyloctanoic and 4-ethyloctanoic acids have been found to be the main volatile compounds responsible for the goat flavour and they are perceived at very low concentration [7, 32].

In recent years, the use of human detectors has been extensively exploited, especially in gas chromatography-olfactometry (GC-O), to investigate the sensory relevance of individual volatiles of substances. GC-O techniques combine the instrumental method of gas chromatography (GC) for the separation of the volatile compounds in the GC column with sensory analysis whereby at the sniffing port, the separated compounds can be sensorially evaluated by a human nose to characterise their aroma qualities and intensities. By comparing olfactometric data with chromatographic data, individual volatiles can be matched with their characteristic odours $[6,26]$.

Sensory analysis is becoming increasingly widespread, and its use may often 
be considered scientifically rigorous; it is a key element in defining cheese quality and is therefore seen as an essential tool in the food industry, particularly in the dairy sector.

Although data about volatile compounds of goat cheese is available [7, 9, $10,15,19,21,22,28,31]$ there is little work on the volatile composition of Spanish goat cheeses [29]. Moreover, only some authors establish a relationship between instrumental and sensory data [22, 28].

The goat cheeses of this study are regionally-produced and are made from goat's milk of different races in different regions of Spain. These cheeses are not protected by a Denomination of Origin, and consequently, they have not been well characterised and their cheesemaking technology is not well established. The aim of this work was to do a preliminary study about the volatile composition of these cheeses and to study the relationship between instrumental data on volatile compounds and sensory data. This approach will contribute to acquiring a deeper knowledge of these cheeses in terms of their aroma characteristics.

\section{MATERIALS AND METHODS}

\subsection{Cheese samples}

Eight commercial samples of semihard goat cheeses from different regions of Spain (Castilla-La Mancha, Andalucía, Extremadura and Canary islands) manufactured with pasteurised milk and by enzymatic coagulation were selected for this study. The cheeses were manufactured with pasteurised goat's milk from goats of different races, following similar traditional technological procedures, which includes enzyme coagulation, the use of a mesophilic commercial mixedstrain starter culture, cutting, pressing and salting, with slight modifications due to the cheesemaker and the geographical origin. The approximate ripening time of the cheeses was indicated on the label by the producers as fresh, semi-cured and cured cheese. A sample wedge weighing roughly $250 \mathrm{~g}$ was cut from each $1.5 \mathrm{-kg}$ cheese for physico-chemical analysis and Simultaneous Distillation Extraction (SDE) analysis. Samples were de-rinded, ground and homogenised in a blender. The remainder of each cheese was used for sensory analysis.

\subsection{Physico-chemical analysis}

Dry matter (DM) was analysed according to the standards of the International Dairy Federation [17]; pH was determined by direct readings using an Ingold insertion electrode; fat content was analysed by the Gerber butyrometric method [27], total nitrogen (TN) using the Kjeldahl method [3] and the salt content $(\mathrm{NaCl})$ was determined using a Chloride Analyser (Sherwood, model 926). All analyses were performed in duplicate.

\subsection{Volatile composition}

Simultaneous Distillation Extraction (SDE) was carried out according to the method proposed by Martínez-Castro et al. [23] using $10 \mathrm{~g}$ of cheese and $2 \mathrm{~mL}$ dichloromethane as extracting solvent and $90 \mu \mathrm{L}$ camphor solution as internal standard (concentration $0.5 \mathrm{mg} \cdot \mathrm{mL}^{-1}$ in absolute ethanol). Extracts were then concentrated under nitrogenous stream to a volume of $100 \mu \mathrm{L}$.

An Agilent gas chromatograph model $6890 \mathrm{~N}$ coupled to a mass selective detector model 5973 inert was used. An amount of $1 \mu \mathrm{L}$ of extract was injected in splitless mode on a BP-21 capillary column $(60 \mathrm{~m} \times 0.25 \mu \mathrm{m}$ i.d. $\times 0.25 \mu \mathrm{m}$ film thickness). The oven temperature programme was: $60{ }^{\circ} \mathrm{C}-4{ }^{\circ} \mathrm{C} \cdot \mathrm{min}^{-1}-190{ }^{\circ} \mathrm{C}$ 
(50 min). Injector and transfer line temperatures were $250{ }^{\circ} \mathrm{C}$ and $280{ }^{\circ} \mathrm{C}$, respectively. Mass detector conditions were: electronic impact (EI) mode at $70 \mathrm{eV}$; source temperature: $178^{\circ} \mathrm{C}$; scanning rate: $1 \mathrm{scan} \cdot \mathrm{s}^{-1}$; mass acquisition range: 40 $450 \mathrm{amu}$. The carrier gas used was helium $\left(28 \mathrm{~cm} \cdot \mathrm{s}^{-1}\right.$ at $\left.100{ }^{\circ} \mathrm{C}\right)$.

Identification of the volatile compounds was performed by comparing their gas chromatographic (GC) retention index and mass spectra with those of authentic standards from Sigma-Aldrich. The tentative identification of compounds for which it was not possible to find reference volatiles was carried out by comparison of their mass spectra with spectral data from the Wiley G 1035 A and NBS75k libraries, and on the basis of a retention index published in the literature [9]. A semi-quantitative analysis was performed assuming that the volatile compounds have the same response factor to that of the internal standard.

\subsection{Gas chromatography- olfactometry analysis}

The organic extracts of cheeses were used for the GC-O analysis. Sniffing was carried out in a Hewlett-Packard model 4890 gas chromatograph equipped with a flame ionisation detector (FID) and sniffing port (SGE) connected by a flow splitter to the column exit. The GC column and method were the same as described above for the analyses of volatile compounds by GC-MS. The carrier gas was $\mathrm{He}\left(24 \mathrm{~cm} \cdot \mathrm{s}^{-1}\right.$ at $\left.100{ }^{\circ} \mathrm{C}\right)$. One $\mu \mathrm{L}$ of extract was injected in the splitless mode, the splitless time being $0.8 \mathrm{~min}$. The injector and detector temperatures were $250{ }^{\circ} \mathrm{C}$ and $280{ }^{\circ} \mathrm{C}$, respectively. Four experienced judges sniffed the organic cheese extracts obtained by SDE; they were asked to assign odour characteristics to each odourant detected and also to assess their odour in- tensities on a three-point scale ( 1 = weak, $2=$ medium, $3=$ intense). No odour detection was assumed to be zero intensity [35]. All cheese extracts were analysed twice.

\subsection{Descriptive sensory analysis}

The sensory analysis was performed by 9 assessors, all staff members of the Department of Food Science and Technology, with previous experience in the sensory evaluation of cheeses $[8,28]$. Samples were cut into cubes of $1.5 \mathrm{~cm}^{3}$ and were served in disposable, odour-free, plastic cups, covered with a watch glass and allowed to reach room temperature before serving. Each panellist was given two samples per session, chosen at random. Cheese samples were identified by 3-character codes. All the samples were tested twice in two different sessions. Nine odour attributes (odour intensity, goat's milk, lactic acid/yoghurt, butter, mouldy, animal, fruity, mushroom and caramel) were chosen by consensus from a list of terms freely generated by the panel, and the panellists evaluated the cheeses using a $10-\mathrm{cm}$ unstructured scale. The bottom end of the scale indicated no perceptible sensation or minimal perceptible sensation and the top end a clearly perceptible sensation.

\subsection{Statistical analysis}

Analysis of variance (ANOVA), using the Student Newman Keuls test $(P<0.05)$ for comparison of the means, and Pearson correlation analysis (using values) were performed. Principal component analysis (PCA) was applied to the volatile compound data using the correlation matrix and Varimax rotation. All these statistical treatments were performed using the SPSS program for Windows, version 13.0 (SPSS Inc., Chicago, IL, USA) and the STATISTICA for Windows package, version 7.1 (StatSoft, Inc., Tulsa, OK 74104, USA). 
Table I. Mean values and standard deviations of the physico-chemical parameters of goat cheeses.

\begin{tabular}{|c|c|c|c|c|c|c|c|}
\hline Samples & Origin* & $\begin{array}{l}\text { Ripening } \\
\text { time*** }\end{array}$ & $\mathrm{pH}$ & $\mathrm{DM}(\%)$ & $\mathrm{TN}(\%)$ & Fat (\%) & $\mathrm{NaCl}(\%)$ \\
\hline 1 & CLM & $\mathrm{S}$ & $5.11 \pm 0.00^{b}$ & $62.76 \pm 0.19^{\mathrm{c}}$ & $3.53 \pm 0.09^{b}$ & $34.25 \pm 0.35^{\mathrm{c}}$ & $1.39 \pm 0.00^{\mathrm{b}}$ \\
\hline 2 & CLM & $\mathrm{F}$ & $5.15 \pm 0.00^{c}$ & $59.74 \pm 0.39^{a}$ & $3.54 \pm 0.06^{\mathrm{b}}$ & $32.00 \pm 0.00^{\mathrm{b}}$ & $1.21 \pm 0.00^{\mathrm{a}}$ \\
\hline 3 & AND & $\mathrm{C}$ & $5.57 \pm 0.01^{\mathrm{f}}$ & $67.19 \pm 0.08^{\mathrm{e}}$ & $3.90 \pm 0.01^{\mathrm{d}}$ & $37.00 \pm 0.00^{\mathrm{d}}$ & $1.59 \pm 0.00^{c}$ \\
\hline 4 & AND & S & $4.85 \pm 0.01^{\mathrm{a}}$ & $62.94 \pm 0.03^{c}$ & $3.27 \pm 0.03^{\mathrm{a}}$ & $38.25 \pm 0.35^{\mathrm{e}}$ & $1.40 \pm 0.00^{\mathrm{b}}$ \\
\hline 5 & CAN & $\mathrm{C}$ & $5.19 \pm 0.01^{\mathrm{d}}$ & $64.79 \pm 0.03^{\mathrm{d}}$ & $3.91 \pm 0.01^{\mathrm{d}}$ & $34.75 \pm 0.35^{c}$ & $1.60 \pm 0.00^{\mathrm{c}}$ \\
\hline 6 & CAN & $\mathrm{F}$ & $5.30 \pm 0.04^{\mathrm{e}}$ & $59.48 \pm 0.11^{\mathrm{a}}$ & $3.81 \pm 0.08^{\mathrm{c}, \mathrm{d}}$ & $30.50 \pm 0.00^{\mathrm{a}}$ & $1.75 \pm 0.00^{\mathrm{d}}$ \\
\hline 7 & EXT & S & $5.19 \pm 0.01^{\mathrm{d}}$ & $63.15 \pm 0.21^{\mathrm{c}}$ & $3.69 \pm 0.05^{\mathrm{c}}$ & $34.75 \pm 0.35^{\mathrm{c}}$ & $2.29 \pm 0.00^{f}$ \\
\hline 8 & EXT & $\mathrm{S}$ & $5.30 \pm 0.04^{\mathrm{e}}$ & $61.90 \pm 0.11^{\mathrm{b}}$ & $3.72 \pm 0.01^{\mathrm{c}}$ & $30.50 \pm 0.00^{\mathrm{a}}$ & $1.96 \pm 0.00^{\mathrm{e}}$ \\
\hline
\end{tabular}

${ }^{\mathrm{a}-\mathrm{e}}$ Means within columns without a common superscript are significantly different $(P \leqslant 0.05)$ according to the Student-Newman-Keuls test.

* Geographical origin: CLM: Castilla-La Mancha; AND: Andalucía; CAN: Canary Islands; EXT: Extremadura.

** Approximate ripening time: F: fresh; S: semi-cured; C: cured.

\section{RESULTS AND DISCUSSION}

\subsection{Physico-chemical analysis}

The results for physico-chemical analysis of Spanish goat cheeses from different Spanish regions are shown in Table I. Cheeses differed significantly $(P<0.05)$ in terms of physico-chemical characteristics. This is probably due to the different milk used in their manufacture and the different ripening times. Other authors have reported similar results for other Spanish goat cheeses, including Majorero [11], Ibores [24] and other regionally-produced goat cheeses [8].

\subsection{Characterisation of volatile compounds}

About 50 volatile compounds were detected by GC-MS analysis, and were classified into the following chemical groups: acids (84\%), ketones (10\%), lactones $(2.5 \%)$, esters $(1.4 \%)$, benzene compounds (1\%), aldehydes $(<1 \%)$, alcohols $(<1 \%)$ and furan compounds $(<1 \%)$ (Tab. II). Fatty acids were the predominant compounds. In Ibores cheese, by contrast, esters were found to be the main volatile compounds, followed by methylketones and alcohols [29]. Carunchia-Whetstine et al. [9], in a GC-O and GC-MS study of fresh chevre-style goat cheese, identified over 80 compounds including ketones, alcohols, aldehydes, fatty acids and furans.

Thirteen fatty acids were identified in the goat cheeses of the present study. Their presence is a function of lipolysis intensity and contributes considerably to flavour formation. These fatty acids were correlated by $\mathrm{GC}-\mathrm{O}$ with the odour descriptors cheese, rancid, fatty, goaty and sweat. 3-Methylbutanoic acid was the fatty acid perceived with the highest intensity by the sniffers. Decanoic acid was present in the highest concentrations, although the response was not proportional to concentration, due to its high odour threshold [30]. Attaie and Ritcher [4] reported that decanoic acid was the most prevalent fatty acid in Cheddar-like hard goat cheese. Octanoic, 4-methyloctanoic and 4-ethyloctanoic acids have been identified as being responsible for specific "goat" flavour $[15,16,21,22]$. In the present work, octanoic acid was detected by $\mathrm{GC} / \mathrm{O}$ as sweaty/fatty/rancid, with medium intensity, and was found in moderate 
Table II. Concentration ranges (mg equivalent to internal standard $\cdot \mathrm{Kg}^{-1}$ ) of volatile compounds of goat cheeses identified by GC-MS and odour description by GC-O.

\begin{tabular}{llclc}
\hline RI & Compounds & Concentration & Odour descriptor ${ }^{\mathrm{a}}$ & Mean $^{\text {intensities }}{ }^{\mathrm{b}}$ \\
\hline & Acids & & & \\
1400 & Acetic acid & $0.00-0.03$ & vinegar & 2 \\
1583 & Butanoic acid & $0.12-1.26$ & rancid cheese & 2 \\
1627 & 3-Methylbutanoic acid & $0.00-0.87$ & sweat, acid, rancid & 3 \\
1700 & Pentanoic acid & $0.03-0.04$ & sweat & 2 \\
1810 & Hexanoic acid & $0.62-6.84$ & cheese/sweet & 2 \\
1905 & Heptanoic acid & $0.00-0.41$ & sweaty/fatty & 1 \\
2015 & Octanoic acid & $1.59-21.30$ & sweaty/fatty/rancid & 2 \\
2134 & 4-Methyl octanoic acid & tr-0.07 & goaty/waxy & 1 \\
2198 & 4-Ethyl octanoic acid & tr-0.01 & goaty & 2 \\
2213 & Decanoic acid & $6.14-58.40$ & rancid/cheese/dry & 1 \\
2315 & Undecanoic acid & $0.12-0.55$ & rancid/dry & 1 \\
2370 & Dodecanoic acid & $1.70-15.70$ & cheese & 1 \\
2538 & Tetradecanoic acid & $1.09-10.87$ & cheese & 1
\end{tabular}

\section{Ketones}

$\begin{array}{ll}1180 & \text { 2-Heptanone } \\ 1276 & \text { 3-Hydroxy-2-butanone } \\ 1289 & \text { 2-Octanone } \\ 1479 & \text { 3-Hydroxy-2-pentanone } \\ 1492 & \text { 2-Hydroxy-3-pentanone } \\ 1390 & \text { 2-Nonanone } \\ 1441 & \text { 8-Nonen-2-one } \\ 1600 & \text { 2-Undecanone } \\ 1896 & \text { 2-Tridecanone } \\ 2013 & \text { 2-Pentadecanone }\end{array}$

0.92-12.89 mushroom 2

$0.10-2.58 \quad$ buttery 2

0.03-0.38 mouldy/humidity 2

$0.00-0.21$ fatty/cream 2

$0.00-0.08$ fatty/cream 1

0.46-14.19 medicinal/sour 2

$0.00-0.17 \quad$ cooked 2

0.10-1.07 cooked 2

$0.13-0.82$ citrus 1

0.22-1.82 cooked 2

\section{Lactones}

$1758 \gamma$-Hexalactone

$2325 \gamma$-Nonalactone (+ nonanoic acid)

2036 ठ-Decalactone

$2485 \gamma$-Decalactone

$2533 \gamma$-Dodecalactone

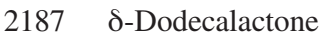

$\begin{array}{lll}0.00-0.05 & \text { fruity } & 2 \\ 0.31-0.81 & \text { fruity } & 2 \\ & & \\ 0.10-0.36 & \text { dairy/sweet } & 3 \\ 0.25-1.06 & \text { fruity } & 2 \\ 0.00-0.27 & \text { dairy/sweet } & 1 \\ 0.14-0.63 & \text { sweet/fruity } & 1\end{array}$

\section{Esters}

1240 Hexanoic acid ethyl ester

$0.00-0.32 \quad$ fruity/green apple $\quad 3$

1439 Octanoic acid ethyl ester $\quad 0.00-0.58$ fruity

1647 Decanoic acid ethyl ester $0.00-1.34$ fruity 2

1903 Dodecanoic acid ethyl ester $\quad 0.00-0.40$ fruity 3

1465 2-Butoxyethyl acetate $\quad 0.00-0.96 \quad$ nd 
Table II. Continued.

\begin{tabular}{lllll}
\hline RI & Compounds & Concentration & Odour descriptor $^{\mathrm{a}}$ & Mean intensities $^{\mathrm{b}}$ \\
\hline & Benzenic compounds & & & \\
1660 & Phenylacetaldehyde & $0.13-0.93$ & dry fruit & 3 \\
1822 & Benzyl alcohol & $0.02-0.43$ & floral/sweet & 2 \\
1938 & 2-Phenylethanol & $0.03-0.48$ & floral/rose & 2 \\
2198 & Eugenol & $0.00-0.07$ & spicy/clove & 2 \\
2065 & 2-Methylphenol & $0.00-0.06$ & medicinal & 1 \\
2074 & 3-Methylphenol & $0.00-0.07$ & medicinal & 1
\end{tabular}

1469 3-Methylthiopropanal

0.00-0.09 cooked/vegetable 3

$0.12-0.69$

oil/fatty

2

\section{Alcohols}

1330 2-Heptanol

$0.02-0.75$

mushroom

2

1360 1-Hexanol

$0.00-0.15$

green

3

1490 2-Ethyl-1-hexanol

$0.00-0.18$

green

2

2023 1-Decanol

$0.00-0.07$

fatty/hay

1

\section{Furanic compounds}

1470 2-Furfural

1598 5-Methyl-2-furfural

$0.00-0.05$

toasty

toasty

1

2014 2-Furanmethanol

$0.00-0.12$

nd

\section{Others}

2517 Cyclohexadecane $0.09-2.87 \quad$ grassy/rancid

a Odour description at the GC sniffing port during GCO.

${ }^{\mathrm{b}}$ Mean intensities were determined from GCO, $n=4$ sniffers.

nd: Not detected.

tr: Traces.

concentrations. 4-Methyloctanoic and 4-ethyloctanoic acids were detected by the sniffers as goaty and were found at very low concentrations. Despite the very low level of 4-ethyloctanoic acid, it was perceived with medium intensity, probably due to its low threshold value. These findings agree with other authors [32]. Butanoic acid, associated by sniffers with rancid cheese, has also been reported in several unripened and ripened cheeses, and is a common constituent of cheese flavour [30].
Among the methylketones detected were 2-heptanone (mushroom), 2octanone (mouldy), 2-nonanone (sour), 8-nonen-2-one (cooked), 2-undecanone (cooked), 2-tridecanone (citrus) and 2-pentadecanone (cooked). These compounds are lipid degradation products formed by $\beta$-oxidation and decarboxylation of fatty acids. The cheeses analysed also contained 3-hydroxy-2-butanone (acetoin), that was associated with buttery odour. Acetoin has also been identified in other goat cheese varieties $[9,10,21]$. 
Diacetyl, with a strong buttery odour, was not analysed by the method used here, because it eluted very close to the solvent. Gómez-Ruíz et al. [14], in a comparative study of artisanal and industrial Manchego cheeses, found that diacetyl and acetoin were abundant in the latter; these two compounds can be derived from citrate by different lactic acid bacteria, especially Lactoccoccus lactis ssp. lactis biovar. diacetylactis, included in the starter composition. Other ketones found in these goat cheeses were 2-hydroxy-3-pentanone (fatty/cream) and 3-hydroxy-2-pentanone (fatty/cream).

The six lactones identified here were mostly associated by GC-O with fruity, sweet and dairy notes. Although present at low concentrations, most of these compounds accounted for high scores in the GC-O analysis. Similar results were reported by Sablé and Cottenceau [30] in an analysis of the odour thresholds and flavour notes of these compounds in different matrices. Carunchia-Whetstine et al. [9], in a study of fresh chevre-style goat cheese, found several $\gamma$-lactones related to sweet aroma and milk fat flavour.

All the esters detected were correlated by GC-O with fruity and dairy notes. Hexanoic acid ethyl ester and dodecanoic acid ethyl ester displayed the highest intensities. Several authors [2, 13] have suggested that most esters have floral and fruity notes and may contribute to aroma by minimising the sharpness and bitterness imparted by fatty acids and amines, respectively. Few published studies address the odour threshold of esters in cheese, although the range of concentrations and sniffer scores recorded here highlight the sensory impact of these compounds.

Aldehydes formed from amino acids by Strecker degradation are not normally found in cheese, as they are immediately reduced to the corresponding alcohols [1]. Two aldehydes were identified here. 3-Methylthiopropanal (veg- etable/potato), found in some samples, is produced from methionine and has been identified in goat cheeses [22].

Several straight-chain alcohols contributed to aroma: 2-heptanol (mushroom) was the compound detected in the highest concentrations; 1-hexanol was the alcohol detected with the highest intensity by GC-O, and was related to green notes. Some of these compounds are formed during milk pasteurisation/heating [18]. 2-Phenylethanol (floral/rose), found in all goat cheeses analysed here, results from phenylalanine degradation and has also been associated previously with floral/rose-like odour [20].

Of the other volatile fractions, furan compounds probably derive from sugar degradation and from the Maillard reaction mechanism. Two of the three furan compounds identified, albeit at low concentrations, were associated by GC-O with toasty notes.

\subsection{Study of volatile composition of cheeses by Principal Component Analysis}

Since the number of variables was very high compared with the number of samples for applying the Principal Component Analysis, ANOVA was performed before PCA to obtain the variables that most contributed to differentiating samples. From this analysis, 23 volatile compounds were chosen and were subjected to the PCA. Three PCs were obtained, that explained $90.9 \%$ of the Total Variance (TV). Figure 1A shows the projection of the samples on the plane formed by the first two PCs. PC1 explained $36.0 \%$ of the TV and was highly correlated with 2-phenylethanol (0.980), decanoic acid ethyl ester (0.912) and 2-pentadecanone (0.902), these compounds being associated by GC-O with "floral/rose", "fruity" and "cooked" notes, respectively (Tab. II). 
A)

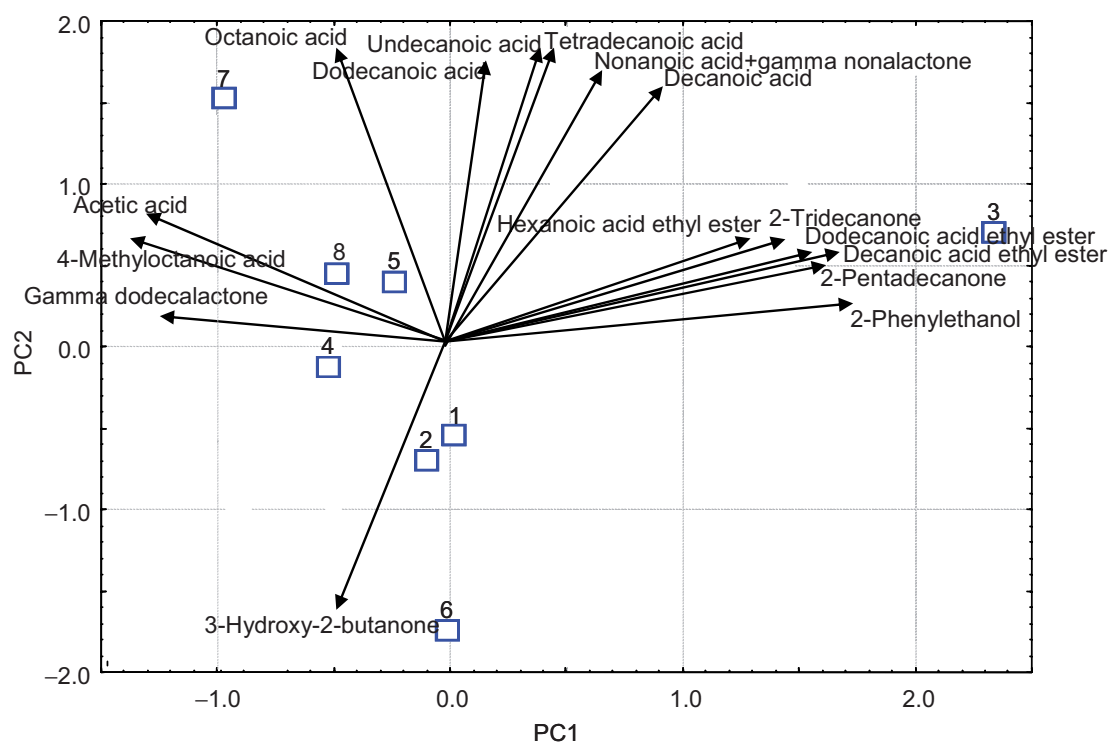

B)

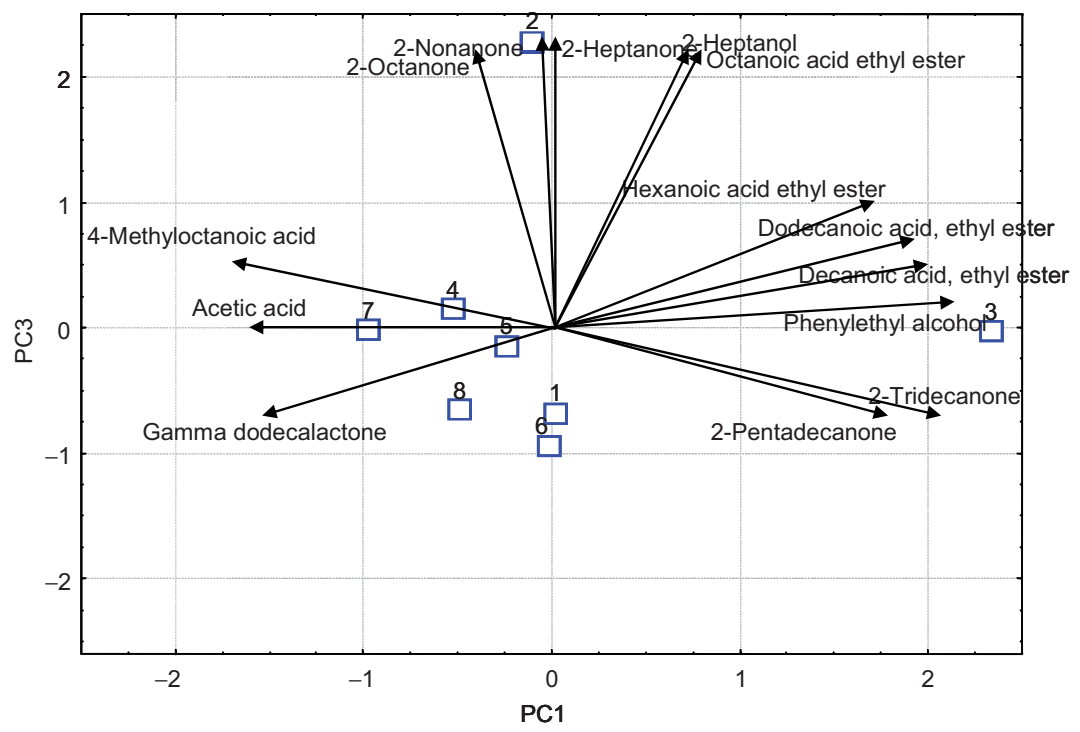

Figure 1. Principal Component Analysis of the volatile compounds by GC-MS. Biplot of the samples and the most significant variables on the planes defined by the three principal components: A) PC 1 and PC 2; B) PC 1 and PC 3. 
Table III. Mean values and standard deviation of the odour attributes evaluated in goat cheeses.

\begin{tabular}{lcccccccc}
\hline & \multicolumn{7}{c}{ Sample } \\
\cline { 2 - 8 } Attribute & 1 & 2 & 3 & 4 & 5 & 6 & 7 & 8 \\
\hline Intensity & $6.1 \pm 0.4^{\mathrm{d}}$ & $7.0 \pm 0.3^{\mathrm{c}}$ & $7.3 \pm 0.2^{\mathrm{e}}$ & $5.2 \pm 0.5^{\mathrm{c}}$ & $4.0 \pm 0.6^{\mathrm{a}, \mathrm{b}}$ & $3.4 \pm 0.3^{\mathrm{a}}$ & $7.5 \pm 0.0^{\mathrm{e}}$ & $4.6 \pm 0.4^{\mathrm{b}, \mathrm{c}}$ \\
Goat's milk $3.7 \pm 0.1^{\mathrm{c}}$ & $1.8 \pm 0.2^{\mathrm{a}, \mathrm{b}}$ & $2.8 \pm 0.0^{\mathrm{b}, \mathrm{c}}$ & $3.6 \pm 0.6^{\mathrm{c}}$ & $0.7 \pm 0.2^{\mathrm{a}}$ & $1.6 \pm 0.5^{\mathrm{a}, \mathrm{b}}$ & $0.6 \pm 0.0^{\mathrm{a}}$ & $1.4 \pm 1.0^{\mathrm{a}}$ \\
Lactic/ & $5.3 \pm 0.0^{\mathrm{b}}$ & $6.0 \pm 0.6^{\mathrm{b}}$ & $2.3 \pm 0.2^{\mathrm{a}}$ & $5.1 \pm 0.2^{\mathrm{b}}$ & $1.3 \pm 0.0^{\mathrm{a}}$ & $3.1 \pm 0.8^{\mathrm{a}}$ & $1.9 \pm 1.0^{\mathrm{a}}$ & $1.9 \pm 0.2^{\mathrm{a}}$ \\
yoghurt & & & & & & & & \\
Butter & $3.5 \pm 0.4^{\mathrm{b}, \mathrm{c}} 4.8 \pm 0.2^{\mathrm{c}}$ & $5.0 \pm 0.1^{\mathrm{c}}$ & $2.7 \pm 0.5^{\mathrm{a}, \mathrm{b}}$ & $4.4 \pm 0.5^{\mathrm{c}}$ & $4.4 \pm 1.0^{\mathrm{c}}$ & $1.8 \pm 0.3^{\mathrm{a}}$ & $4.8 \pm 0.1^{\mathrm{c}}$ \\
Mouldy & $0.1 \pm 0.2^{\mathrm{a}}$ & $0.8 \pm 1.1^{\mathrm{a}}$ & $0.1 \pm 0.2^{\mathrm{a}}$ & $0.0 \pm 0.0^{\mathrm{a}}$ & $0.5 \pm 0.7^{\mathrm{a}}$ & $0.0 \pm 0.0^{\mathrm{a}}$ & $1.4 \pm 0.1^{\mathrm{a}}$ & $0.1 \pm 0.1^{\mathrm{a}}$ \\
Animal & $2.2 \pm 0.3^{\mathrm{c}}$ & $1.7 \pm 0.2^{\mathrm{b}, \mathrm{c}}$ & $2.5 \pm 0.3^{\mathrm{c}}$ & $0.8 \pm 1.1^{\mathrm{a}, \mathrm{b}}$ & $0.0 \pm 0.0^{\mathrm{a}}$ & $0.0 \pm 0.0^{\mathrm{a}}$ & $4.1 \pm 0.2^{\mathrm{d}}$ & $0.2 \pm 0.0^{\mathrm{a}}$ \\
Fruity & $1.3 \pm 0.2^{\mathrm{a}}$ & $0.9 \pm 0.6^{\mathrm{a}}$ & $1.2 \pm 0.2^{\mathrm{a}}$ & $1.2 \pm 0.1^{\mathrm{a}}$ & $2.8 \pm 0.3^{\mathrm{a}}$ & $3.2 \pm 2.0^{\mathrm{a}}$ & $0.5 \pm 0.7^{\mathrm{a}}$ & $1.0 \pm 0.2^{\mathrm{a}}$ \\
Mushroom & $0.0 \pm 0.0^{\mathrm{a}}$ & $0.3 \pm 0.1^{\mathrm{a}}$ & $0.0 \pm 0.0^{\mathrm{a}}$ & $0.0 \pm 0.0^{\mathrm{a}}$ & $0.0 \pm 0.0^{\mathrm{a}}$ & $0.0 \pm 0.0^{\mathrm{a}}$ & $0.0 \pm 0.0^{\mathrm{a}}$ & $0.0 \pm 0.0^{\mathrm{a}}$ \\
Caramel & $0.8 \pm 0.2^{\mathrm{b}, \mathrm{c}}$ & $0.2 \pm 0.2^{\mathrm{a}, \mathrm{b}}$ & $1.0 \pm 0.2^{\mathrm{b}, \mathrm{c}}$ & $0.0 \pm 0.0^{\mathrm{a}}$ & $3.3 \pm 0.6^{\mathrm{d}}$ & $1.2 \pm 0.2^{\mathrm{c}}$ & $1.0 \pm 0.1^{\mathrm{b}, \mathrm{c}}$ & $1.0 \pm 0.1^{\mathrm{b}, \mathrm{c}}$ \\
\hline
\end{tabular}

${ }^{\mathrm{a}-\mathrm{e}}$ Means within rows without a common superscript are significantly different $(P \leqslant 0.05)$ according to the Student-Newman-Keuls test.

This PC separated cheese sample 3 from the rest in terms of its high content of these compounds, which could be associated with the long ripening time of this sample. PC $2(30.5 \%$ TV) was correlated with the free fatty acids octanoic (0.919), tetradecanoic (0.908), undecanoic (0.888) and dodecanoic (0.885), its odour descriptors by GC-O being "sweaty/fatty", "cheese" and "rancid". This PC separated samples 7 and 6 from the rest, in terms of their, respectively, high and low content of these free fatty acids. Moreover, sample 6 was separated from the rest by its higher concentration of 3-hydroxy-2-butanone, related by $\mathrm{GC}-\mathrm{O}$ to the buttery descriptor. PC $3(24.4 \%$ TV) was highly correlated with 2-heptanone (0.965), 2-nonanone (0.940), 2-heptanol (0.936) and 2-octanone (0.933); these compounds were related by GC-O to the attributes "mushroom", "medicinal/sour", "mushroom", and "mouldy/humidity", respectively. This PC separated sample 2 from the rest in terms of its high content of these compounds (Fig. 1B). Some of the volatile compounds highly correlated with the $3 \mathrm{PCs}$ in the present study (2-phenylethanol, octanoic acid, 2-heptanone and 2-nonanone) have been found to be related to the typical goat cheese aroma [21]. Samples did not distribute either according to their ripening time or according to their geographical origin.

\subsection{Relationship between volatile composition and sensory data}

The mean scores awarded by panellists to each of the attributes evaluated are shown in Table III. Scores suggest that these cheeses were generally characterised by considerable odour intensity and moderately intense buttery aroma. The buttery aroma may be prompted by both diacetyl and 3-hydroxy-2-butanone; using $\mathrm{GC}-\mathrm{O}$, the latter displayed a fairly intense buttery aroma. Cheeses 1, 3 and 4 received the highest scores for the goat's milk odour. Three samples displayed an intermediate lactic acid/yoghurt odour, significantly higher than the rest. Cheese sample 7 was scored highest for animal odour; this sample had the highest shortand medium-chain fatty acid content (results not shown). These compounds were associated by GC-O with a sour/rancid odour. Cheeses 5 and 6 obtained the highest scores for fruity odour. Caramel notes 
Table IV. Pearson correlation coefficients between volatile compounds and sensory descriptors.

\begin{tabular}{llc}
\hline Sensory descriptor & Volatile compound & Correlation coefficient \\
\hline Animal & Octanoic acid & $0.669^{*}$ \\
& Decanoic acid & $0.748^{*}$ \\
& Tetradecanoic acid & $0.673^{*}$ \\
Odour intensity & Decanoic acid & $0.675^{*}$ \\
Mouldy & 2-Heptanone & $0.720^{*}$ \\
Mushroom & 2-Heptanone & $0.893^{* *}$ \\
& 2-Heptanol & $0.941^{* *}$ \\
Lactic acid/yoghurt & Pentanoic acid & $0.875^{*}$ \\
& 2-Nonanone & $0.699^{*}$ \\
Goat's milk & --Decalactone & $0.692^{*}$ \\
& $\gamma$-Dodecalactone & $0.801^{* *}$ \\
Fruity & 1-Hexanol & $0.923^{*}$ \\
Caramel & $\delta$-Dodecalactone & $0.704^{*}$ \\
\hline
\end{tabular}

$* P<0.05 ; * * P<0.01$.

were only detected with any intensity in one sample and mould and mushroom attributes were barely detected by panellists.

Application of Pearson's correlation analysis to volatile compounds identified by GC and sensory attributes disclosed good correlation coefficient values for some samples (Table IV). Medium-chain fatty acids (octanoic, decanoic and tetradecanoic acids) correlated positively $(P<$ $0.05)$ with animal odour. Sniffers associated these acids with the descriptors sweat, rancid and fatty, which may be related to animal odour.

2-Nonanone displayed strong correlation with lactic acid/yoghurt odour. This compound was described as sour by GC-O, which may be related to the lactic acid odour reported by panellists. Both $\delta$-decalactone and $\gamma$-dodecalactone correlated strongly with goat's milk odour, whereas these compounds were associated by GC-O with the "dairy" descriptor. A number of studies suggest that lactones are associated with dairy and fruity aromas [5, 33], but have never been related to typical goat's milk odour. These correlations suggest that the sensory perception of an individual molecule (by GC-O) is different from the perception of the same molecule in mixture and in interaction with the food matrix.

\section{CONCLUSIONS}

The compounds analysed by SDE contributing most to the aroma of these goat cheeses were short-chain fatty acids, especially 3-methylbutanoic acid (rancid cheese), numerous ketones, some lactones including $\delta$-decalactone (dairy/sweet), ethyl esters of hexanoic (fruity/green apple) and dodecanoic (fruity) acids, some benzene compounds including phenylacetaldehyde (dry fruit), and also 1-hexanol (green).

The application of PCA to the volatile compounds obtained by GC-MS distinguished four samples from the rest in terms of their different content of some specific volatile compounds. A good correlation between some sensory attributes and specific volatile compounds was observed. However, it is difficult to establish a relationship between the odour descriptors perceived by GC-O and the sensory attributes evaluated by the panellists in the cheese, 
since cheese contains a wide range of compounds which interact, giving rise to an overall aroma sensation which cannot easily be predicted using individual volatile compound descriptors.

Acknowledgements: The authors thank the Universidad de Castilla-La Mancha for financial support provided for this research and P.J. Martín-Álvarez for help with the statistical treatment.

\section{REFERENCES}

[1] Adda J., Gripon J.C., Vassal L., The chemistry of flavour and texture generation in cheeese, Food Chem. 9 (1982) 115-129.

[2] Anderson D.F., Day E.A., Quantification, evaluation and effect of certain microorganisms on flavour components of Blue cheese, J. Agr. Food Chem. 14 (1966) 241-245.

[3] Association of Official Agricultural Chemists (AOAC), Official methods of analysis (15th edn.), Washington, D.C., Horwith, 1995.

[4] Attaie R., Richter R.L., Formation of volatile free fatty acid during ripening of Cheddarlike hard goat cheese, J. Dairy Sci. 79 (1996) 717-724.

[5] Belitz H.D., Grosch W., Food Chemistry, Springer-Verlag, Berlin, Germany, 1997.

[6] Blank I., Gas chromatography-olfactometry in food aroma analysis, in: Marsili R. (Ed.), Flavour, Fragrance and Odour Analysis, Marcel Dekker, New York, USA, 2002, pp. 297-298.

[7] Brennand C.P., Ha J.K., Lindsay R.C., Aroma properties and threshold of some branched-chain and other minor volatile fatty acids occurring in milkfat and meat lipids, $\mathbf{J}$. Sens. Stud. 4 (1989) 105-120.

[8] Cabezas L., Poveda J.M., Sánchez I., Palop M.L.L., Physico-chemical and sensory characteristics of Spanish goat cheeses, Milchwissenschaft 60 (2005) 48-51.

[9] Carunchia-Whetstine M.E., Karagul-Yuceer Y., Avsar Y.K., Drake M.A., Identification and quantification of character aroma components in fresh chevre-style goat cheese, Food Chem. Toxicol. 68 (2003) 2441-2447.
[10] Engel E., Lombardot J.B., Garem A., Leconte N., Septier C., Le Queré J.L., Salles C., Fractionation of the water-soluble extract of a cheese made from goats' milk by filtration methods: behaviour of fat and volatile compounds, Int. Dairy J. 12 (2002) 609-619.

[11] Fernández-Salguero J., Barreto J.D., Marsilla B.A., Electroforesis cuantitativa y datos composicionales del queso de Fuerteventura, Alimentaria 119 (1981) 71-80.

[12] Fox P.F., Guinee T.P., Cogan T.M., McSweeney P.L.H., Cheese flavour, in: Fox P.F., Guinee T.P., Cogan T.M., McSweeney P.L.H. (Eds.), Fundamentals of Cheese Science, Aspen Publishers, Gaithersburg, Maryland, USA, 2000, pp. 282-303.

[13] Gallois A., Langlois D., New results in the volatile odorous compounds of French cheeses, Lait 70 (1990) 89-106.

[14] Gómez-Ruíz J.A., Ballesteros C., GonzálezViñas M.A., Cabezas L., Martínez-Castro I., Relationships between volatile compounds and odour in Manchego cheese: comparison between artisanal and industrial cheeses at different ripening times, Lait 82 (2002) 613828.

[15] Ha J.K, Lindsay R.C., Volatile branchedchain fatty acids and phenolic compounds in aged Italian cheese flavours, J. Food Sci. 56 (1991) 1241-1250.

[16] Ha J.K., Lindsay R.C., Contribution of cow, sheep and goat milks to characterizing branched-chain fatty acid and phenolic flavours in varietal cheeses, J. Dairy Sci. 74 (1991) 3267-3274.

[17] IDF-FIL, Fromages et fromages fondus, Détermination de l'extrait sec total; méthode de référence, Norme FIL 4A, International Dairy Federation, Brussels, 1982.

[18] Karagul-Yuceer Y., Cadwallader K.R., Drake M.A., Volatile flavor components of stored non-fat dry milk, J. Agr. Food Chem. 50 (2002) 305-312.

[19] Kim G., Lee J.H., Min D.B., Study of lightinduced volatile compounds in goat's milk cheese, J. Agr. Food Chem. 51 (2003) 14051409.

[20] Kubickova J., Grosch W., Evaluation of potent odorants of Camembert cheese by dilution and concentration techniques, Int. Dairy J. 7 (1997) 65-70.

[21] Le Queré J.L., Pierre A., Riaublanc A., Demaizières D., Characterization of aroma 
compounds in the volatile fraction of soft goat cheese during ripening, Lait 78 (1998) 279-290.

[22] Le Quéré J.L., Septier C., Demaizières D., Salles C., Identification and sensory evaluation of the character-impact compounds of goat cheese flavour, Eighth Weurman Flavour Research Symposium, Reading, July 23-26, 1996, Royal Society of Chemistry, Cambridge, UK.

[23] Martínez-Castro I., Sanz J., Amigo L., Ramos M., Martín-Álvarez P., Volatile components of Manchego cheese, J. Dairy Res. 58 (1991) 239-246.

[24] Mas Mayoral M., Timón-Esteban J.T., González Crespo J., Queso de los Ibores: caracterización productiva, físico-química y microbiológica, Arch. Zootec. 40 (1991) 103113.

[25] Ministerio de Agricultura, Pesca y Alimentación, Estadística Láctea Nacional, Madrid, Spain (2005).

[26] Mistry B.S., Reineccius T., Olson L.K., Gas chromatography-olfactometry for the determination of key odorants in foods, in: Marsili R. (Ed.), Techniques for Analysing Food Aroma, Marcel Dekker, New York, USA, 1997, pp. 265-289.

[27] Netherlands Standard NEN 3059, Butyrometric determination of the fat content of cheese (Gerber-Van Gulik method), Neth. Milk Dairy J. 23 (1969) 214-220.
[28] Poveda J.M., Cabezas L., Free fatty acid composition of regionally-produced Spanish goat cheese and relationships with the sensory characteristics, Food Chem. 95 (2006) 307-311.

[29] Sabio E., Vidal-Aragón C., Análisis de la fracción volátil del queso de los Ibores, Alimentaria 278 (1996) 101-103.

[30] Sablé S., Cottenceau G., Current knowledge of soft cheeses flavour and related compounds, J. Agr. Food Chem. 47 (1999) 48254836.

[31] Sablé S., Letellier F., Cottenceau G., An analysis of the volatile flavour compounds in a soft raw goat milk cheese, Biotechnol. Lett. 19 (1997) 143-145.

[32] Salles C., Sommerer N., Septier C., Issanchou S., Chabanet C., Garem A., Le Quéré J.L., Goat cheese flavor: sensory evaluation of branched-chain fatty acids and small peptides, J. Food Sci. 67 (2002) 835-841.

[33] Scanian R.A., Lindsay R.C., Libbey L.M., Day E.A., Heat-induced volatile compounds in milk, J. Dairy Sci. 51 (1968) 1001-1007.

[34] Urbach G., The flavour of milk and dairy products, Int. J. Dairy Technol. 50 (1997) 79-89.

[35] Van Ruth S.M., Methods for gas chromatography olfactometry: a review, Biomol. Eng. 17 (2001) 121-128. 